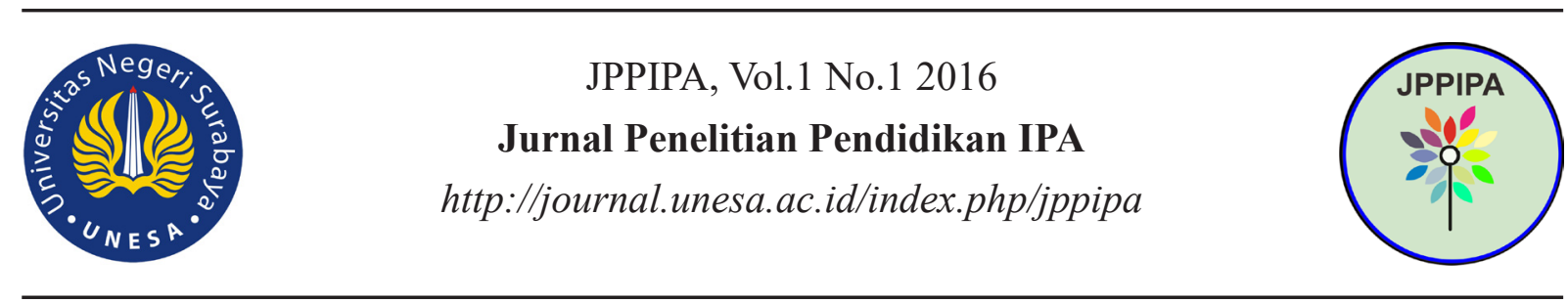

\title{
PENERAPAN STRATEGI PEMBELAJARAN INKUIRI TERBIMBING BERBANTUAN MEDIA UNTUK MENINGKATKAN KETERAMPILAN BERPIKIR ILMIAH SISWA PADA PEMBELAJARAN IPA SMP
}

Oleh:

Ida Fitriyati ${ }^{1}$, Munzil ${ }^{2}$

${ }^{1}$ Pendidikan Dasar Pascasarjana Universitas Negeri Malang

${ }^{2}$ Pendidikan IPA Universitas Negeri Malang

\begin{abstract}
Abstrak
Penelitian ini bertujuan untuk mendeskripsikan pengaruh model pembelajaran inkuiri terbimbing berbantuan media dalam meningkatkan keterampilan berpikir ilmiah siswa SMP pada pembelajaran IPA. Penelitian dilakukan pada siswa kelas VIII SMP Negeri 3 Sanggau Kalimantan Barat. Penelitian ini merupakan penelitian tindakan kelas dengan model Kemmis dan Taggard dengan 3 siklus, tiap siklus terdiri dari tahapan perencanaan, tindakan, pengamatan dan refleksi. Materi IPA yang diberikan dalam pembelajaran adalah tekanan dan bunyi, sedangkan media yang digunakan adalah media sederhana yang ada dalam kehidupan sehari-hari. Pengambilan data dilakukan dengan teknik observasi terhadap hasil kerja siswa dalam memecahkan masalah yang diberikan. Hasil penelitian menunjukkan terjadi peningkatan keterampilan berpikir ilmiah siswa dari siklus 1 sampai siklus 3. Pada siklus 1 rata-rata keterampilan berpikir ilmiah siswa mencapai $70 \%$, pada siklus 2 naik menjadi $75 \%$ dan pada siklus 3 mengalami peningkatan menjadi $83.75 \%$.
\end{abstract}

Kata Kunci: model pembelajaran inkuiri, media pembelajaran, dan kemampuan berpikir ilmiah

\begin{abstract}
The purpose of this research was to describe the effect of guided inquiry learning model with the aid of media in terms of enhancing junior high school students' scientific thinking skills in science learning. The research involved students of 8th grade of SMP Negeri 3 Sanggau, West Kalimantan. Action research was the design of this research at which it was based on the model advocated by Kemmis and Taggard consisting three cycles, planning, acting, observing, and reflecting. The topic given was pressure and sound and its learning was facilitated by the media easily found in the daily life. The data was observed and analyzed in a descriptive manner. The results showed that students'scientific thinking skills were successfully promoted by which the skills percentage increase from $70 \%$ in stage 1 to $83.75 \%$ in stage 3 . In summary, inquiry learning model embedded with the use of media for learning can support students to get more skills in scientific ways.
\end{abstract}

Keywords: inquiry learning model, media for learning, and scientific thinking skills

C 2016 Universitas Negeri Surabaya

${ }^{2}$ Alamat Korespondensi:

p-ISSN: 2527-7537

Program Studi Pendidikan IPA, Fakultas Matematika

e-ISSN: 2549-2209

dan Ilmu Pengetahuan Alam, Universitas Negeri

Malang, Malang, Indonesia

Email: munzil.fmipa@um.ac.id 


\section{PENDAHULUAN}

Ilmu pengetahuan alam (sains) dalam pembelajaran di sekolah dapat dipandang dari dua sisi, yaitu sains sebagai sebuah produk kerja ilmuan, dan sains dipandang sebagai proses ilmuwan bekerja untuk menghasilkan pengetahuan (Waldrip, Prain, \& Carolan, 2010). Kedua pandangan tersebut akan membawa dampak yang berbeda dalam pelaksanaan pembelajaran di kelas.

Pembelajaran sains yang hanya memberi tahu siswa tentang fakta, konsep, teori dan hukum, tanpa memberi kesempatan siswa untuk mendapatkannya sendiri, merupakan dampak dari pandangan bahwa sains hanyalah sebuah produk kerja ilmuwan. Pandangan tersebut biasanya diwujudkan dalam pembelajaran dikelas dengan teknik ceramah (expository). Siswa hanya hanya dianggap sebagai objek pasif dalam menerima pengetahuan yang diberikan guru.

Pandangan kedua, sains sebagai proses ilmuwan bekerja dalam menemukan ilmu pengetahuan, dalam pembelajaran di kelas akan menempatkan siswa sebagai orang yang dapat mencari, mengolah dan menemukan sendiri ilmu pengetahuan tersebut sehingga dalam pembelajarannya lebih menekankan pada proses penemuan pengetahuan dari pada pengetahuannya itu sendiri. Dalam kelas siswa dididik untuk dapat mengenali fakta, mengetahui perbedaan dan persamaan fakta, mencari hubungan antar fakta, hingga siswa dapat mengkonstruksi pengetahuannya secara mandiri. Pandangan ini sangat sesuai dengan kurikulum 2013, yang menekankan pada penggunakan pendekatan saintifik dalam pembelajaran di sekolah.

Dampak pembelajaran sains yang menggunakan strategi ceramah terhadap rendahnya keaktifan dan prestasi siswa telah banyak dilaporkan oleh beberapa peneliti. Keadaan tersebut nampak juga pada siswa kelas VIII SMP Negeri 3 Sanggau Kalimantan Barat pada semester gasal 2014/2015, prestasi belajar IPA masih belum menggembirakan. Siswa yang mencapai KKM masih dibawah $50 \%$.

Hasil wawancara dengan siswa, menunjukkan bahwa siswa kurang menyukai penggunaan metode ceramah pada pembelajaran sains. Selama ini pembelajaran IPA memang didominasi dengan teknik ceramah, mengingat keterbatasan alat-alat laboratorium untuk percobaan IPA. Sajian materi yang cenderung dijelaskan, ternyata menjadi beban bagi siswa. Beberapa siswa menyatakan sangat kesulitan untuk mengingat beberapa rumus yang telah dijelaskan guru. Kondisi pembelajaran tersebut di atas, pada dasarnya tidak sesuai untuk pembelajaran tujuan sains. Salah satu tujuan pembelajaran sains adalah untuk mengembangkan kemampuan berpikir tingkat tinggi siswa (Cheung, 2008).

Berdasarkan kondisi pembelajaran di atas, maka perlu dicarikan pemecahan masalah, agar pembelajaran IPA menjadi pembelajaran yang menyenangkan dan dapat mendorong kemampuan berpikir tingkat tinggi siswa. Kemampuan berpikir tingkat tinggi siswa tidak serta merta tumbuh dengan sendirinya, tetapi melalui proses latihan dan pengalaman. Salah satu sistem yang dapat memberi pengalaman agar siswa dapat mengembangkan kemampuan berpikir tingkat tingginya adalah melalui sistem pembelajaran di kelas (Alghafri \& Ismail,2014).

Salah satu tahapan untuk mencapai kemampuan berpikir tingkat tinggi adalah melalui tahapan keterampilan berpikir ilmiah (Jo \& Bednarz, 2015). Keterampilan berpikir ilmiah akan memberi pengalaman pada siswa untuk berpikir logis dan sistematis. Berpikir ilmiah dimulai dari kecermatan siswa dalam melihat fakta atau fenomena, merumuskan hipotesis, merancang percobaan, memprediksi data, menganalisis data dan menarik kesimpulan (Timostsuk, 2015). Untuk mendorong siswa agar dapat melakukan tahapan berpikir ilmiah, dibutuhkan media yang dapat diamati secara langsung.

Para ahli pembelajaran banyak mengupas beberapa strategi pembelajaran yang dapat mendorong keterampilan berpikir ilmiah siswa. Beberapa strategi yang disarankan diantaranya strategi inquiry, discovery, problem based, problem posing, dan lain sebagainya.

Strategi yang umum dan mudah dipraktekkan dalam pembelajaran di kelas adalah inkuiri. Menurut Suchman (1996) dalam Zubaidah (2013) inkuiri sebagai suatu pencarian kebenaran, informasi, atau pengetahuan upaya pencarian tersebut di lakukan melalui pertanyaan. Selanjutnya di kemukakan, mengetahui cara belajar lebih penting daripada mengetahui semua jawaban, maka harus disadari bahwa pertanyaan yang baik lebih penting dari pada jawaban yang benar. Mengajar siswa untuk bertanya dan mengajukan pertanyaan bermakna lebih penting dari pada kebenaran jawaban yang diberikan. Salah satu kelebihan inkuiri di antaranya: siswa lebih dilibatkan aktif dalam mengkonstruksi pengetahuan, memperoleh informasi, mengorganisasi informasi, memecahkan masalah, dan mencari kebenaran atau pengetahuan, daripada mengkonsumsi pengetahuan.

Strategi Inkuiri terdiri dari 4 level, yaitu level ke 0, 1, 2, dan level 3 (Fay, Grove, Towns, \& Bretz, 2007). Level ke 0 , semua perangkat mulai dari masalah, metode dan cara penyelesaikan disediakan oleh guru, siswa hanya tinggal menjalankan saja. Inkuiri level 1, masalah dan prosedur diberikan oleh guru, siswa diminta untuk menginterpretasikan data yang diperoleh. Inkuri Level 2, hanya masalah yang diberikan pada siswa, sedang cara menyelesaikan dan interpretasi data diserahkan pada siswa. Sedangkan inkuiri level 3, guru hanya memberikan fenomena saja, siswa diminta mencari masalah dan menyelesaikannya secara mandiri. Inkuiri level 1 dan 2, sering disebut dengan inkuiri terbimbing.

Inkuiri terbimbing, sangat cocok diterapkan untuk membelajarkan siswa dalam berpikir ilmiah. Strategi pembelajaran inkuiri terbimbing memberi bantuan pada siswa untuk bekerja sebagaimana ilmuwan bekerja mendapatkan pengetahuannya. Inkuiri terbimbing dapat membantu siswa untuk setahap demi setahap membiasakan diri berpikir secara ilmiah (Moore, Herzog, \& Perkins, 2013).

Penggunaan media pembelajaran dapat membantu siswa dalam memahami fenomena dan mengkondisikannya menjadi ilmu pengetahuan. Gag- 
ne (1970) dalam Sutarman, Endang (2013), media adalah berbagai jenis komponen dalam lingkungan siswa yang dapat merangsang untuk belajar, kehadiran media dalam pembelajaran diharapkan dapat memotivasi siswa untuk berfikir dan bertanya, menarik perhatian siswa dan meningkatkan minat belajarnya sehingga terjadi proses belajar yang lebih efisien.

Keterampilan berpikir ilmiah merupakan keterampilan berpikir yang dapat diajarkan pada siswa. Komponen-komponen dalam berpikir ilmiah adalah kemampuan mengamati atau mengidenfikasi fakta atau fenomena, kemampuan merumuskan masalah, kemampuan eksplorasi data untuk mendukung pemecahan masalah dan kemampuan merumuskan kesimpulan yang terkait dengan masalah yang ingin diselasaikan.

Berdasarkan kajian di atas, maka untuk strategi pembelajaran inkuiri terbimbing berbantuan media digunakan untuk meningkatkan kemampuan berpikir ilmiah siswa.

\section{METODE}

Penelitian ini menggunakan penelitian tindakan kelas model Kemmis dan Taggard dengan dua siklus. Masing-masing siklus terdiri dari tahapan:(1) perencanaan pembelajaran, yaitu langkah-langkah pembelajaran yang akan dilakukan disusun dan dicermati tentang kemungkinan langkah-langkah tersebut dapat berhasil atau tidak untuk diimplementasikan, (2) pelaksanaan pembelajaran menyangkut cara siswa diberi perlakuan (treatment). Ketika pelaksanaan, guru akan dapat menambahkan aktivitas yang mungkin lebih operasional dan efektif (3) pengamatan pembelajaran (observasi) dilakukan oleh pengamat yang telah lebih dahulu memahami poin-poin penilaian ,dan (4) refleksi pembelajaran terkait dengan langkah-langkah alternatif yang dapat digunakan untuk mengubah atau memodifikasi langkah-langkah pada tahap sebelumnya yang dinilai tidak berhasil dilakukan di kelas. Masing-masing siklus berhubungan satu dengan yang lainnya. Hasil refleksi pembelajaran pada siklus I digunakan sebagai bahan untuk perbaikan pembelajaran pada siklus II. Model penelitian tindakan kelas Kemmis dan Taggard disajikan pada gambar dibawah ini.

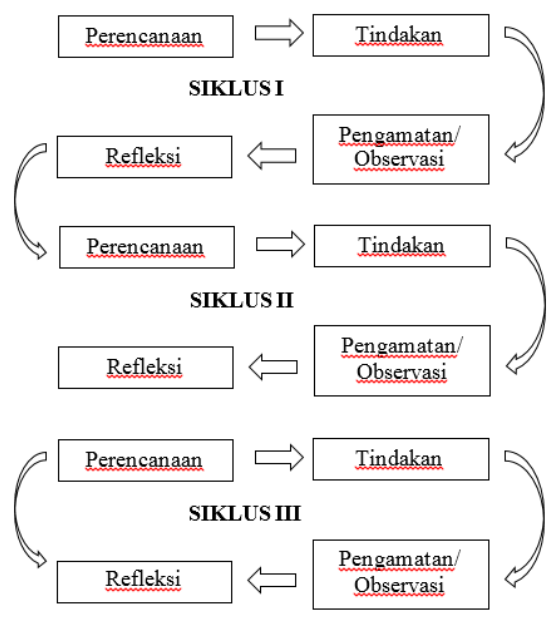

Gambar 1. PTK Model Kemmis dan Taggard (1988)
Subyek penelitian adalah 30 siswa kelas VIII B SMPN 3 Sanggau, yang terdiri dari 12 Lakil-laki dan 18 perempuan. Materi pelajaran yang digunakan dalam penelitian adalah tentang tekanan dan bunyi. Penelitian dilakukan pada bulan Februari 2015. Instrumen penelitian berupa lembar observasi keterlakasanaan pembelajaran, dan LKS siswa. LKS siswa digunakan sebagai instrument untuk mengetahui keterampilan berpikir ilmiah siswa, karena LKS sudah disusun mengarah pada proses berpikir ilmiah. Teknik analisis data menggunakan teknik analisis deskriptif. Pertanyaan-pertanyaan dan analisis data yang ada di LKS disusun untuk mendeteksi kemampuan berpikir ilmiah siswa.

\section{HASIL DAN PEMBAHASAN}

\section{Hasil Pengamatan Pembelajaran Siklus I}

Pembelajaran pada siklus 1 tentang konsep tekanan diberikan dalam bentuk praktikum secara berkelompok, dengan anggota tiap kelompok 4 siswa. Media yang digunakan plastisin dan uang koin logam. Tujuan percobaan dimaksudkan agar siswa dapat memahami tentang konsep tekanan dan hubungannya dengan gaya dan posisi koin (luas permukaan). Pada akhir percobaan siswa diminta untuk melakukan analisis hubungan antara bekas kedalam (sebagai akibat dari gaya yang diberikan) dengan posisi koin pada plastisin. Pembelajaran diawali dengan mengajak siswa untuk menyusun hipotesis tentang hubungan antara kedalam bekas koin dan posisi koin pada plastisin. Dari hipotesis yang disusun, siswa diminta untuk menyusun rangkaian percobaan yang akan dilakukan.

Rumusan hipotesis tentang hubungan antara besarnya tekanan dan kedalaman bekas koin pada plastisin pada semua kelompok sudah benar, baik pada posisi koin tegak maupun pada posisi mendatar. Hal ini menunjukkan bahwa siswa sudah dapat merumuskan hipotesis dengan baik. Langkah - langkah percobaan yang disusun pada setiap kelompok sangat beragam, tetapi pada dasarnya ada kesesuaian antara hipotesis yang disusun dengan rancangan percobaan yang akan dilakukan. Kelemahan terjadi saat siswa menarik kesimpulan dari data percobaan yang diperoleh.

Perumusan hipotesis siswa sangat baik, hal ini karena percobaan yang dilakukan bersifat kontekstual, dalam arti siswa mudah untuk membayangkan apa yang akan terjadi jika koin ditekan pada permukaan plastisin. Demikian juga ketika siswa diminta untuk merancang percobaan untuk membuktikan hipotesis yang disusun, rata-rata semua kelompok dapat merancang dengan baik.

Dari hasil kerja siswa di LKS, menunjukkan akurasi data yang dihasilkan termasuk pada kategori baik, yaitu saat siswa mengisi komponen pengamatan apa yang harus diamati selama percobaan. Data yang diperoleh berhubungan dengan besar tekanan, posisi koin pada plastisin, dan tingkat kedalaman bekas koin pada plastisin. Hasil kerja ini menunjukkan, kemampuan siswa sudah cukup baik dalam 
Tabel 1. Skor komponen berpikir ilmiah siswa pada siklus I

\begin{tabular}{llc}
\hline No & Komponen Pengamatan & Skor Rata- Rata \\
\hline 1 & Penyusunan hipotesis & 85 \\
2 & Rancangan rangkaian percobaan & 85 \\
3 & Akurasi data pengamatan & 70 \\
4 & Penarikan kesimpulan & 40 \\
\hline & Rata-rata & $\mathbf{7 0}$ \\
\hline
\end{tabular}

menyusun rangkaian percobaan dan mengambil data yang sesuai dengan percobaannya.

Kelemahan terjadi saat siswa diminta untuk menyimpulkan hasil percobaan tersebut, yaitu yang berhubungan dengan faktor-faktor yang mempengaruhi besar tekanan. Beberapa kesimpulan yang ditulis oleh masing-masing kelompok diantaranya adalah sebagai berikut:

Kelompok 1: kedalaman bekas lubang sangat tergantung pada faktor dorongan dan posisi uang logam yang diamati

Kelompok 2: kedalaman bekas lubang sangat tergantung pada dorongan dan posisi

Kelompok 3: Posisi berdiri memberi bekas lubang yang dalam, sedangkan posisi uang logam berbaring memberikan pengaruh yang kecil

Kelompok 4: kedalaman bekas lubang dipengaruhi oleh gaya yang bekerja pada sebuah benda

Kelompok 5: kedalaman bekas lubang dipengaruhi oleh sisi logam dan tekanan

Dari beberapa kesimpulan yang diajukan tersebut, dapat diketahui bahwa siswa masih belum dapat mengaitkan antara satu data dengan data yang lain untuk ditarik menjadi sebuah kesimpulan. Mereka masih merasa kesulitan untuk mencari pola dan cara data-data itu dapat dihubungkan satu sam lain untuk menjelaskan konsep.

Hasil analisis pembelajaran dari siklus 1 menunjukkan bahwa siswa masih mengalami kesulitan saat memprediksi data yang akan diperoleh, sehingga siswa tidak mengetahui apakah data yang diperoleh sudah benar atau salah, akibatnya pada penarikan kesimpulan yang benar. Kemampuan memprediksi data percobaan sangat diperlukan dalam pembelajaran sains dan merupakan salah satu bagian dari keterampilan berpikir ilmiah (Acar Sesen \& Tarhan, 2013). Pemberian bantuan pada siswa untuk dapat memprediksi dan melakukan analisis data akan membantu siswa untuk dalam melakukan proses ilmiah (Land \& Zembal-Saul, 2003).

Hasil refleksi ini dijadikan dasar pada perbaikan pembelajaran selanjutnya. Hal-hal yang diperbaiki adalah sebagai berikut: (1) meminta siswa untuk memprediksi data yang akan diperoleh dari rancangan percobaan yang dilakukan, dan (2) meminta siswa untuk menarik kesimpulan sementara dari rancangan data yang diperolehnya.

\section{Hasil Pengamatan Pembelajaran Siklus II}

Materi pada siklus 2 tentangpengaruh tekanan pada zat cair. Media yang digunakan adalah botol bekas air mineral 1,5L dan air. Pembelajaran diawali dengan mengajak siswa menyusun hipotesis tentang pengaruh tekanan pada zat cair, dengan menggunakan botol yang telah dilubangi. Pembelajaran kemudian dilanjutkan dengan meminta siswa untuk menyusun rancangan percobaan yangakan dilakukan untuk membuktikan hipotesis yang diajukan. Siswa diminta juga untuk memprediksi data yang akandiperolehjika percobaan dilakukan, kemudian siswa diminta juga untuk merumuskan kesimpulan yang akan diperoleh dari percobaan yang akan dilakukan. Hasil pengamatan pada proses pembelajaran pada siklus 2 disajikan pada tabel berikut ini:

Tabel 2. Skor komponen berpikir ilmiah siswa pada siklus II

\begin{tabular}{llc}
\hline No & Komponen Pengamatan & Skor Rerata \\
\hline 1 & Penyusunan hipotesis & 80 \\
2 & Rancangan rangkaian percobaan & 80 \\
3 & Akurasi data pengamatan & 80 \\
4 & Penarikan simpulan & 60 \\
\hline & Rata-rata & $\mathbf{7 5}$ \\
\hline
\end{tabular}

Perumusan hipotesis mengalami penurunan dibandingkan dengan siklus 1 , hal dimungkinkan karena untuk merumuskan hipotesis tentang hubungan tinggi lubang dengan panjang lintasan air, membutuhkan pemahaman tentang konsep tekanan yang benar. Disamping itu fenomena percobaan yang dilakukan siswa jarang dijumpai dalam kehidupan sehari-hari. Siswa akan lebih mudah menduga atau memprediksi gejala atau fenomena jika fenomena tersebut sering dijumpai dalam kehidupan nyata (Saglam, Karaaslan, \& Ayas, 2011). Oleh karena itu dalam pembelajaran ilmu pengetahuan alam perlu menyajikan faktafakta atau fenomena yang ada disekitarsiswa.

Rancangan percobaan yang disusun siswa sudah sesuai dengan hipotesis yang diajukan, yaitu tentang 
posisi lubang pada botol dan volume air yang harus diisi kedalam botol. Kemampuan prediksi siswa terhadap data percobaan yang akan diperoleh selama percobaan, tergolong cukup. Dari 5 kelompok, hanya 1 kelompok yang memprediksi bahwa lintasan air yang diperoleh pada semua posisi adalah sama. Hal ini sejalan dengan rumusan hipotesis yang diajukan. Berdasarkan konsistensi rumusan hipotesis dan prediksi peroleh data, menunjukkan bahwa siswa sudah memiliki kemampuan menghubungkan perubahan antar variabel.

Akurasi data hasil pengamatan tergolong baik, yaitu pengamatan terhadap panjang lintasan air yang keluar dari lubang botol. Dari 5 kelompok 4 kelompok menyajikan data dengan benar, sedangkan 1 kelompok menyajikan data kurang sesuai. Ketidaksesuaian pengamatan kelompok tersebut, dimungkinkan dipengaruh hipotesis dan prediksi data percobaan yang telah disusun. Data pengamatan yang disajikan tidak menekankan pada perbedaan jarak turunnya air, tetapi menekankan pada debit air yang keluar pada lubang botol.

Kemampuan siswa dalam menarik kesimpulan belum mengalami perubahan yang berarti dibandingkan pada siklus 1 . Siswa cenderung menghubungkan fakta-fakta secara fisik saja, tanpa menarik konsep dari fakta - fakta yang ditemukan. Beberapa simpulan yang diajukan oleh siswa adalah sebagai berikut:

Kelompok 1: Semakin besarnya kedalam zat cair, maka semakin besar pula tekanan zat cair tersebut.

Kelompok 2: Semakin banyak air yang keluar semakin banyak pula daya tekannya

Kelompok 3: Semakin dalam zat cair semakin besar tekanannya

Kelompok4:TitikC(titikterdekat)tekannyasangatkecil
Kelompok 5: Zat cair dan tekanan zat cair sama-sama mempunyai tekanan zat padat.

Kelemahan pada siklus 2 yang sangat utama adalah pada kemampuan siswa dalam memprediksi hasil percobaan dan penarikan kesimpulan. Masih terdapat kelompok siswa, prediksi data percobaannya tidak sesuai dengan hipotesis yang telah dirumuskan. Hal ini ternyata berdampak pada kemampuan siswa dalam menyusun kesimpulannya.

Berdasarkan temuan tersebut, maka pada siklus 3 dilakukan perubahan, yaitu memberikan penguatan yang lebih pada saat siswa diminta untuk memprediksi hasil pengamatan dan penarikan kesimpulan. Penguatan dilakukan dengan diskusi antar kelompok, agar terjadi proses elaborasi dan verifikasi pemahaman siswa.

\section{Hasil Pengamatan Pembelajaran Siklus III}

Perubahan tindakan mendasar yang dilakukan pada siklus 3 adalah diberikannya kesempatan antar kelompok untuk saling berdiskusi tentang prediksi data pengamatan yang akan diperoleh melalui percobaan. Tujuan pemberian kesempatan diskusi ini adalah, agar antar kelompok saling bertukar pendapat. Diskusi merupakan salah satu cara kerja ilmuwan dalam mengkonstruksi temuan yang diperolehnya, serta merupakan salah satu sarana untuk melakukan verifikasi temuannya. Pembelajaran pada siklus3 adalah tentang identifikasi hukum Pascal. Siswa diminta untuk mengisi plastik yang telah diberi lubang kecil sebanyak 4 buah pada posisi yang berbeda dengan air, kemudian plastik ditekan, dan siswa diminta untuk mengamati lintasan air yang keluar dari plastik tersebut. Kemudian siswa diminta untuk menyimpulkan dari praktikum tersebut seperti yang tersaji pada tabel berikut, sebagaimana terlihat ada empat komponen penilaian.

Tabel 3. Skor hasil belajar pada siklus III

\begin{tabular}{llc}
\hline No & Komponen Pengamatan & Skor Rerata \\
\hline 1 & Penyusunan hipotesis & 85 \\
2 & Rancangan rangkaian percobaan & 90 \\
3 & Akurasi data pengamatan & 90 \\
4 & Penarikan simpulan & 70 \\
\hline & Rata-rata & $\mathbf{8 3 . 7 5}$ \\
\hline
\end{tabular}

Berdasarkan hasil pengamatan proses pembelajaran, perumusan hipotesis tentang besarnya tekanan yang diberikan plastik (yang berisi air) terhadap debit air yang keluar pada masing-masing lubang, umumnya baik. Semua kelompok membuat rumusan hipotesis yang menyatakan bahwa air akan keluar dari masing-masing lubang dengan kekuatan yang sama. Kebenaran perumusan hipotesis ini tidak lepas dari masalah yang diberikan pada siswa, cukup dekat dengan kehidupan nyatanya. Permasalahan yang bersifat kontekstual akan membantu siswa untuk dapat memecahkannya (Saglam et al., 2011).

Rancangan percobaan yang disusun oleh mas- ing-masing kelompok sangat baik, semua kelompok menyusun rancangan percobaan sesuai dengan hipotesis yang diajukan. Kebenaran rancangan percobaan ini tidak lepas dari hasil diskusi antara kelompok dalam membuat rancangan percobaan. Terdapat 2 kelompok yang mengalami perubahan rancangan percobaan setelah berdiskusi dengan kelompok lain. Perubahan rancangan percobaan yang dilakukan kelompok tersebut menunjukkan sikap-sikap ilmiah yang sangat baik, yaitu dapat menerima masukan dari pihak lain.

Akurasi hasil pengamatan sangat baik, semua kelompok memiliki data percobaan yang sudah benar 
sesuai dengan hipotesis yang diajukan. Keakuratan data percobaan ini tidak lepas dari bimbingan yang diberikan pada siswa untuk memprediksi data percobaan. Terdapat 2 kelompok mengulangi percobaannya, karena data yang diperoleh tidak sesuai dengan prediksinya. Hal ini menunjukkan kemampuan siswa untuk melakukan verifikasi data yang kurang sesuai sudah mulai tumbuh. Kemampuan memprediksi data percobaan dan melakukan verfikasi data percobaan merupakan salah satu indikator dari kemampuan berpikir ilmiah (Kuhn, 2010).

Kemampuan siswa dalam menarik kesimpulan belummengalamiperubahanyangberartidibandingkan pada siklus 2. Siswa cenderung menghubungkan fakta-fakta secara fisik saja, tanpa menarik konsep dari fakta- fakta yang ditemukan. Beberapa kesimpulan yang diajukan oleh siswa adalah sebagai berikut: Kelompok 1: Semakin besar tekanan pada zat cair semakin besar juga titik air (derasnya air keluar)

Kelompok 2: Jika plastik ditekan maka tekanan pada air tersebut akan semakin besar

Kelompok 3: air yang ditekan akan keluar karena diberi tekanan yang cukup kuat sehingga airnya keluar

Kelompok 4: Ketika air di dalam plastik itu dibolongkan dan diberi tekanan,maka air tersebut akan keluar dengan merata sampai habis

Kelompok 5: Semakin dalam zat cair maka tekanannya semakin besar

Secara umum kesimpulan tersebut sudah sesuai dengan fakta pengamatan, tetapi masih belum bisa menghubungkan antar konsep tekanan dan penyebarannya. Penarikan kesimpulan adalah merupakan salah satu kegiatan utama seorang ilmuwan, kesimpulan merupakan wujud dari proses berpikir ilmiah (Glazer, 2015). Oleh karena itu kemampuan siswa dalam menyusun kesimpulan berdasarkan data - data percobaan yang diperoleh sangat perlu untuk dilatihkan.

\section{SIMPULAN}

Berdasarkan hasil pengamatan pembelajaran, dapat disimpulkan sebagai berikut:

1. Penerapan strategi pembelajaran inkuiri terbimbing berbantuan media dapat meningkatkan keterampilan berpikir ilmiah siswa.

2. Media sangat membantu siswa untuk dapat mengkonstruksi konsep tentang tekanan.

\section{DAFTAR PUSTAKA}

Acar Sesen, B., \& Tarhan, L. (2013). Inquiry- Based Laboratory Activities in Electrochemistry: High School Students' Achievements and Attitudes. Research in Science Education, 43(1), 413-435.
Alghafri, A. S. R., \& Ismail, H. N. Bin. (2014). The Effects of Integrating Creative and Critical Thinking on Schools Students' Thinking. International Journal of Social Science and Humanity, 4(6),518-525.

Cheung, D. (2008). Facilitating chemistry teachers to implement inquiry-based laboratory work. International Journal of Science and Mathematics Education, 6(1), 107-130.

Fay, M. E., Grove, N. P., Towns, M. H., \& Bretz, S. L. (2007). A rubric to characterize inquiry in the undergraduate chemistry laboratory. Chem. Educ. Res. Pract ., 8(2),212-219

Glazer, N. (2015). Student perceptions of learning data-creation and data-analysis skills in an introductory college-level chemistry course. Chemistry Education Research and Practice, 16(2),338-345.

Jo, I., \& Bednarz, S. W. (2015). Developing pre-serviceteachers' pedagogical content knowledge for teaching spatial thinking through geography. Journal of Geography in Higher Education, 8265(October)

Kemmis, S. \& Robin McTaggart. 1988. The Action Research Planner. Victoria: Deakin University Press.

Kuhn, D. 2010. Teaching and learning science as argument. Science Education, 94(5), 810-824.

Land, S. M., \& Zembal-Saul, C. 2003. Scaffolding reflection and articulation of scientific explanations in a data-rich, project-based learning environment: An investigation of progress portfolio. Educational Technology Research and Development, 51(4), 65-84.

Moore, E. B., Herzog, T. a, \& Perkins, K. K. 2013. Interactive simulations as implicit support for guided-inquiry. Chemistry Education Research and Practice, 14(3), 257-268.

Saglam, Y., Karaaslan, E., \& Ayas, A. 2011. the Impact of Contextual Factors on the Use of Students'Conceptions. International Journal of Science, (October 2009), 1391-1413.

Sutarman, Endang, K. Media Pembelajaran Sains SMP. Malang: Kerjasama PT. Pertamina (Persero) dengan Universitas Negeri Malang

Timostsuk, I. (2015). Domains of Science Pedagogical Content Knowledge in Primary Student Teachers Practice Experiences. Procedia - Social and Behavioral Sciences, 197 (February), 1665-1671.

Waldrip, B., Prain, V., \& Carolan, J. (2010). Using multi-modal representations to improve learning in junior secondary science. Research in Science Education, 40(1), 65-80.

Zubaidah, S., yuliati, L., Mahanal, S. 2013. Model dan Metode Pembelajaran SMP IPA. Malang: Kerjasama PT. Pertamina (Persero) dengan Universitas Negeri Malang. 